Reynolds in fact explicates Abe Kōbō's The Box Man, in terms of its urban space/visuality nexus, which is a subject of Prichard's chapter 4. Thus, more extensive engagement with Reynolds's work would be desirable.

On a more technical note, Japanese titles/terms are often not represented, even when there is no existing translation or established English equivalent; instead, only their approximate English translation is provided in the main body, the notes, or the index. Readers would benefit from being able to look further into such sources with the citation of original titles and terms, at least in their first appearance in the volume. It would also be highly desirable to correlate reprinted images with applicable passages in which they are closely and insightfully explicated (as, for example, on pages 168 and 186), so that readers could collate the two mediums point by point, verifying the author's argument. There should also be a list of illustrations and a list of copyright owners (only the cover photo is credited in full, on the back cover).

Residual Futures addresses timely critical issues that many of us share and has succeeded in creating a network of considerations across premeditated disciplines. With its examinations of documentary film, which is by default multimedia, and of visually oriented authors such as Abe and textually prolific artists such as Nakahira, this book will command attention from a wide range of scholars and other critically minded readers to urgent consideration of these registers, as well as of the urban space they formed and transformed. I congratulate the author on the wonderful beginning of what promises to be a long and productive journey.

\title{
An Anthology of Kokugaku Scholars: 1690-1868
}

By John R. Bentley. Ithaca, N. Y.: Cornell East Asian Series, 2017. x, 596 pp. $\$ 45.00$.

\section{Reviewed by \\ Clarence I-Zhuen Lee}

The importance of the Edo period movement called Kokugaku (lit. the study of the country) cannot be understated, from its appropriation by Mito domain scholars to renovate the decaying Tokugawa social order in the nineteenth century, to its usage in the ideology of the Japanese colonial empire in the 1930s and 1940s,

Japanese Language and Literature $\mid$ jll.pitt.edu

Vol. 54 | Number 1 | April 2020 | DOI: https://doi.org/10.5195/j11.2020.149 
Kokugaku writings have often been used (or misused) as central currents undergirding the history of cultural nationalism in modern Japan. In this regard, John R. Bentley's An Anthology of Kokugaku Scholars: 1690-1868 provides a timely collection of important Kokugaku writings, some of which are translated for the first time into the English language.

Before going into the main aims of the anthology, it should be noted that an immediately recognizable strength of Bentley's translation lies in his choice to leave the term Kokugaku untranslated. In his highly informative introduction to the anthology, Bentley begins with a brief history of important Japanese and English language scholarship written about Kokugaku. By first surveying modern writings in Japan, he demonstrates how the term's definition has changed over the past century depending on the perspective each modern scholar took. As his survey concludes, Kokugaku as a movement is immensely difficult to define due to its ambiguous conceptual and intellectual boundaries. Aggravating this situation is the fact that scholars writing in the English language often "translate" the term either as "nativism," or the anachronistic (and highly problematic) "national learning." Instead of falling back onto these established customs of rendering the term into its English "equivalent," Bentley rightly points out that they merely serve to distort Kokugaku by over-emphasizing its relation to modern Japanese nationalism. Following Mark Teeuwen's observation in "Kokugaku vs. Nativism" (Monumenta Nipponica 61.2) that "not all nativism was Kokugaku, nor was nativism all there was to Kokugaku," Bentley therefore attempts to circumvent this teleological error of defining Kokugaku as a form of "protonationalism" by proposing the main aim of the anthology: instead of providing a precise definition (translation) of Kokugaku, the anthology will place on display the multifaceted nature of the movement. The anthology is therefore "constructed ... along a chronological axis, demarcated by themes to illustrate the diversity of thought as well as the evolution of the various schools" (7). According to Bentley, the central tenet of Kokugaku was its emphasis on the role of poetry in society and how it enabled readers to return to the pristine age of antiquity in their present. It is for this

Japanese Language and Literature $\mid$ jll.pitt.edu

Vol. 54 | Number 1 | April 2020 | DOI: https://doi.org/10.5195/j11.2020.149 
reason that the translations in the anthology, while separated into four thematic groups, begin with the section subtitled "Views on Poetry." The other three sections, equal in length to the first, are "Views on Literature," "Views on Scholarship," and lastly, "Views on Japan/religion."

Although this reviewer agrees with the reasons for leaving the central term "Kokugaku" untranslated, the lack of any primarily definition does, however, raise the question of how the anthology was framed, and how each of the primary texts were selected. An indication lies in Bentley's adherence to Teeuwen's main assertion stated above that nativism and Kokugaku are not equivalent. In his review article, Teeuwen asserts that translating (i.e. equating) Kokugaku as "nativism" is erroneous as it prevents the possibility of seeing Kokugaku as a movement that can be defined as something other than "anti-foreign." According to Teeuwen then, scholars who seek to study the movement must pay attention to "the role of poetry exchanges as the glue that kept Kokugaku together, and also to the long history of nativist poetics that Kokugaku inherited" (italics are mine). While this is an important dimension that is often forgotten when Kokugaku is taught in the classroom, we can ask the following question: what exactly is "nativist poetics"? It appears that for Teeuwen, as for Bentley, what constitutes "nativist poetics" is selfevident, and it is likely that as a categorization, it refers to treatises investigating canonically "Japanese" works, such as The Tale of Genji and the Kokinsh $\bar{u}$. It is needless to say that such a category would only later be defined in the first decades of the Meiji period within the modern disciplinary boundaries of kokubungaku or "national literature," in which everything "non-Japanese" was purged from its canonical boundaries. To limit the study of Kokugaku to its place in the long history of "Japanese poetics" is severely narrow, and this is especially so given the fact that to some Kokugaku scholars "native" and "foreign" are not always mutually exclusive. As modern scholars such as Hino Tatsuo have pointed out, eighteenth century Kokugaku scholars were very much influenced by the anti-Confucian philosophies of Lao $\mathrm{Zi}$ and $\mathrm{Zhuang} \mathrm{Zi}$, and these scholars often adopted these anti-Confucian understandings of natural (onozukara) in their creation of Kokugaku poetics. In spite

Japanese Language and Literature $\mid$ jll.pitt.edu

Vol. 54 | Number 1 | April 2020 | DOI: https://doi.org/10.5195/j1l.2020.149 
of such observations that productively show the complexity of Kokugaku, the reader senses that it is only by assuming the implicit definition of Kokugaku texts as referring to the group of treatises on "Japanese poetics" that enables Bentley to state, "while we could claim that Kokugaku meant whatever each individual scholar wanted it to mean, there are enough commonalities among the schools to demonstrate that in many cases the focus of study was $\alpha$ ["Japanese"?] and not $\beta$ ["foreign"?]" (3; words in brackets are mine). This is perhaps also the reason why in majority of the translated passages in the anthology, the phrases wagakuni ("our country/province") or honcho ("our institution") were often translated/collapsed into the concept of "Japan" or "Japanese" without any explanation of the possible anachronistic slippages that such moves might entail.

A cursory look at the treatises translated reveals the above observation that as an anthology, it is compiled with the frame of "Kokugaku equals nativist (Japanese) poetics" in mind. As Susan Burns has pointed out in Before the Nation (Duke University Press, 2003), post-Meiji period Kokugaku scholarship often emphasized the centrality of the "four great men of Kokugaku," namely, Kada no Azumaro, Kamo no Mabuchi, Motoori Norinaga and Hirata Atsutane. Conceptually similar to Hegel's "great men in History," these four individuals were positioned as important "heroes" in the "cultural" history of Japan. Tomiko Yoda has also pointed out in Gender and National Literature (Duke University Press, 2004) that this narrowing of Kokugaku to the four men can be traced to the scholarship done at academic institutions during Japan's imperial age-scholarship that sought to posit Japan's national continuity with earlier historical periods. Unsurprisingly, it is this historical lineage of "great men" which would eventually facilitate the ideological readings of the Kojiki and the Nihonshoki as "history" in the 1930s and 1940s. Given the problematic nature of viewing Kokugaku as centered around these four historical figures, it is surprising then that of the twenty-six treatises that are included in the anthology, a total of eighteen belonged to the "four great men" mentioned above. In this regard, in spite of the introspective aim of the anthology to illustrate the diversity in Kokugaku, this reviewer

Japanese Language and Literature $\mid$ jll.pitt.edu

Vol. 54 | Number 1 | April 2020 | DOI: https://doi.org/10.5195/j1l.2020.149 
worries that by tilting the balance heavily toward the writings of these four men, the anthology might provide uninformed readers a skewed version of Kokugaku that is dangerously similar to the problematic narrative of a "Japanese" continuity that Yoda and Burns had attempted to historicize.

If readers are able to peruse beyond these issues of framing, the translations are admirably approachable and coherent. Each text does well in providing a nascent researcher of Kokugaku glimpses of its respective ideas and arguments. With concise paragraphsummaries prefacing each treatise that are in-turn categorized systematically under one of the four fore-mentioned sections, Bentley's anthology is by far the most accessible volume of Kokugaku writings in the English language. Given the complex architectonic style in which Kokugaku scholars are known to write their treatises, Bentley's included footnotes are consistently useful in providing the necessary background and bibliographic information to the general reader while laudably not overcrowding the main portions of the text.

However, this reviewer did find some translations that could perhaps have included more explication in corresponding footnotes. For instance, in the translation of Keichū's Man'yō Daishōki, we see the following passage:

In China they put description ahead of content, but in our country we put content ahead of description. Thus when you read Chinese works you have to read it with these two ideas reversed. For example in Japanese we say

花を見、月を待つ, but in China they write 見花、待月.... (34)

In the corresponding original Edo period text, the first sentence goes, "morokoshi ni wa kotowari o saki ni ihite koto o nochi ni ihi, honchō ni wa koto o saki ni ihite kotowari o nochi ni ifu." Bentley rendered kotowari (理) as "description" when it referred in this context to the "concept" (i. e., the way a person interacts with the world around them). Similarly, koto was rendered ambiguously as "content" when it likely referred to phenomenal "things" or "events" in the world. Though there is a certain amount of room for interpretation when it comes to these concepts, there is also a danger of losing clarity if the translations are left ambiguous. Given that the

Japanese Language and Literature $\mid$ jll.pitt.edu

Vol. 54 | Number 1 | April 2020 | DOI: https://doi.org/10.5195/j11.2020.149 
concept of kotowari overlaps with its Neo-Confucian counterpart of the same character ( $l i$, principle), readers would have likely appreciated a footnote explaining the interpretive decision.

A similar interpretive license is also shown in the translation of Kamo no Mabuchi's Bun'ikō where the central concept of 文 (fumi or bun) is rendered as "literature":

People who lived in the divine age put their uncontrollable feelings within their hearts into expression through song. This is known as uta. When the eye witnessed something or the ear heard something, and the ancient Japanese (kamitsuyo no hito) could not keep his feelings to himself, he would thus string words together and vocalize these. These words are called words of praise (tataegoto). Later ages labeled this "literature" (fumi) (173).

In line with the implicit frame elaborated above, we can see here that "people of antiquity" (kamitsuyo no hito) is simply translated as "ancient Japanese." At the same time, we see that the concept of fumi is also being juxtaposed with uta (song) a conceptual binary which Mabuchi maintains throughout Bun'ikō. It is well known that Mabuchi had uncritically adopted the definition of uta as a spontaneous vocal expression of human feelings from the kana preface of the Kokin wakash $\bar{u}$, and that he tried to infuse in fumi a similar spontaneity that is expressed when one interacts with the "outside world." In this sense, translating fumi as "literature" commits a severe conceptual slippage given that the meaning of fumi is likely closer to "text," or simply "descriptive writings." As if to ensure an adequate fit of Mabuchi's treatise with the thematic section of "Views on Literature," Bentley, by translating fumi as "literature," not only superimposes Mabuchi's ideas onto the modern distinction of prose (literature) and poetry - indeed, as Tomi Suzuki has pointed out in The Cambridge History of Japanese Literature (Cambridge University Press, 2016), the modern notion of literature (bungaku) would only emerge in the context of Japan in the late 1880s after its separation from "national history" (kokushi) (564-565) - he also obscures the enormous influence Mabuchi had on later Kokugakusha such as Ban Kōkei (1733-1806), who had tried to create an experiential written "style" of fumi to adequate in describing the everyday. In this sense, this reviewer fears that the four thematic groups ("poetry," "literature," "scholarship," and

Japanese Language and Literature $\mid$ jll.pitt.edu

Vol. 54 | Number 1 | April 2020 | DOI: https://doi.org/10.5195/j11.2020.149 
"Japan/religion") might merely serve to provide an anachronistic set of hermeneutic frames without necessarily achieving the anthology's aim of "illustrat[ing] the diversity of thought [and] the evolution of the various [Kokugaku] schools" (7).

In its presentation and translation of important Kokugaku texts that have hitherto not been adequately examined in English language scholarship, this anthology makes an important contribution to the study of this historically significant movement. However, its anachronistic frames as well as its assumption of implicit nativism should best be viewed with some skepticism. Ultimately, this collection does not seem intended as an engagement with the question, "What is Kokugaku?" in spite of the anthology's aim of putting it on display. This task is rather left up to the reader, along with ample tools to approach this formidable task.

\section{“Joryū" hōdan: Shōwa o ikita josei sakka-tachi}

By Irmela Hijiya-Kirschnereit. Tokyo: Iwanami shoten, 2018. 405 pp. $¥ 3,190$.

\section{Reviewed by Noriko J. Horiguchi}

"Joryū" hōdan: Shōwa o ikita josei sakka-tachi ("Women's style" free conversations: Women writers who lived through the Shōwa era, <女流> 放談—昭和を生きた女性作家達) combines (1) Irmela Hijiya-irschnereit's 2018 essay “'Joryū bungaku' ga bungaku ni naru hi: Josei sakka ga morashita 'nama' no koe" (The day "women's literature" becomes literature: Women writers' "raw" voices), and (2) a collection of her 1980s interviews of twelve well-known modern Japanese women authors: Sata Ineko (1904-1998), Enchi Fumiko (1905-1986), Kono Taeko (19262015), Ishimure Michiko (1927-2018), Tanabe Seiko (1928-), Saegusa Kazuko (1929-2003), Ōba Minako (1930-2007), Togawa Masako (19312016), Tsushima Yuko (1947-2016), Kanai Mieko (1947-), and Nakayama Chinatsu (1948-). Also included are Hijiya-Kirschnereit's 2018 interview of Setouchi Jakuchō (1922-) and Itō Hiromi’s brief 2018 essay about the interviews. Although Hijiya-Kirschnereit's original

Japanese Language and Literature $\mid$ jll.pitt.edu

Vol. 54 | Number 1 | April 2020 | DOI: https://doi.org/10.5195/j11.2020.145 